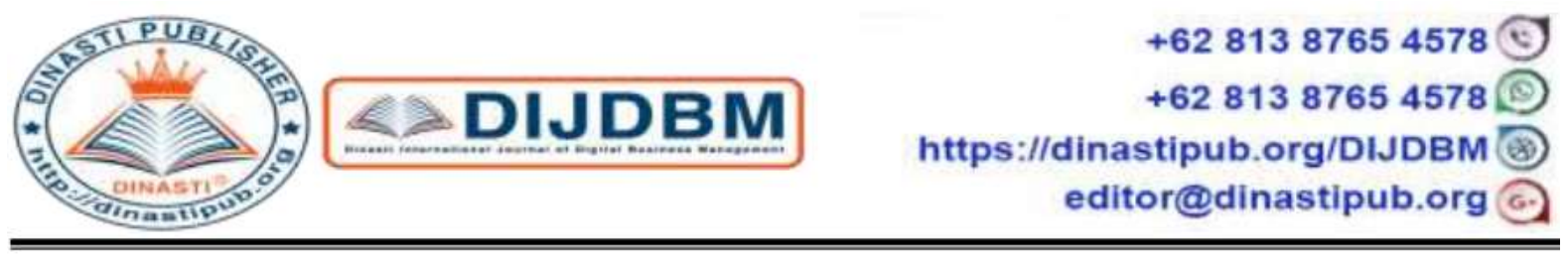

\title{
MODEL OF BANKRUPTCY PREDICTION SERVICES COMPANY SECTOR RETAIL IN INDONESIA STOCK EXCHANGE (Study Case Period 2015 - 2017)
}

\section{Rina Indriani ${ }^{1)}$, Hakiman Thamrin ${ }^{2)}$ \\ ${ }^{1,2}$ Master of Management, Mercubuana University, Jakarta, Indonesia}

ARTICLE INFORMATION

Received: 15 January 2020

Revised: 01 Febuary 2020

Issued: 07 Febuary 2020

(filled in by Editor)

Corresponding author: first author

E-mail:

indrianirina48@gmail.com;

hakiman.thamrin@mercubuana.ac.id

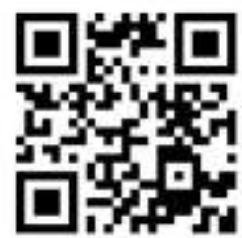

DOI:10.31933/DIJDBM
Abstract: This study aims to identify the dominant causes in forming a bankruptcy prediction model of retail trade service companies listed on the Indonesia Stock Exchange in the 2015-2017 period. The 20152017 observation period with a sample of 20 companies met the criteria as a sample. This research variable is divided into 2 namely dependent and independent variables. The dependent variable in this study is categorical data which is divided into two categories: unhealthy companies symbolized by the number 0 and healthy companies category symbolized by the number 1 . The independent variables in this study are 20 financial ratios, among others, Current Ratio, Quick Ratio, Cash Ratio , Working Capital to Total Assets, Debt to Asset Ratio, Debt to Equity Ratio, Time Interest Earned, Working Capital Turn Over, Fixed Asset Turn Over, Receivable Turn Over, Total Asset Turn Over, Inventory Turn Over, Cash Turn Over, Cash Profit Margin, Operating Profit Margin, Gross Profit Margin, Return On Equity, Return On Assets, Return On Investment, Earning Per Share. The analytical method used is discriminant analysis. Discriminant Test Results using the stepwise method can be obtained variables that are selected as discriminator variables, namely the variable Debt to Equity Ratio, Return On Equity, and Earning Per Share to form discriminant functions as follows:

$R=-3,197+0.292$ Debt to Equity Ratio + 0.342 Return On Equity + 0.336 Earning Per Share

The cut-off value in this study is 0 with a $75 \%$ prediction accuracy in unhealthy service companies and $73.3 \%$ in healthy service companies with an accuracy rate of $76.7 \%$ in retail trade service companies. 
Keywords: Bankruptcy, Retail Companies, Financial Ratios, Multiple Discriminant Analysis (MDA).

\section{INTRODUCTION}

Today's economy is faced with an increasingly strong digital era, so companies need to prepare strategies to face this national and international scale competition so that they can compete and operate properly companies need to develop innovation, improve performance, and pay attention to the company's financial condition. is a financial problem in a company that can't be handled. Not a few companies in Indonesia are experiencing financial distress. One company that is unable to survive in the retail industry services sector is 7 Eleven owned by PT Modern Sevel Indonesia, a subsidiary of PT Modern Internasional Tbk (MDRN). The conventional outlet, known for its Slurpee drink and worldwide, began to experience a shrinking in operating units in 2015, then in the third quarter of 2016, MDRN sales dropped 31 percent from Rp 962.80 billion to Rp 660.67 billion. Meanwhile throughout 2017, the company also suffered a loss of Rp 162.02 billion. Whereas in 2015, MDRN earned a profit of $\mathrm{Rp} 11.77$ billion. The value of the company's equity also dropped from $\mathrm{Rp} 1.2$ trillion to $\mathrm{Rp} 1.1$ trillion. Likewise, the value of assets dropped from $\mathrm{Rp} 2.4$ trillion to $\mathrm{Rp} 2.3$ trillion. Until June 30, 2017, 7-Eleven outlets in Indonesia were officially closed. Sevel only lasted about 8 years in Indonesia. The number of company closures in Indonesia was also strengthened by the presence of companies that were delisted on the Indonesia Stock Exchange (IDX). For six years there have been at least 23 companies delisted from the IDX. The following data are services and manufacturing companies that were delisted during 2013 - 2018:

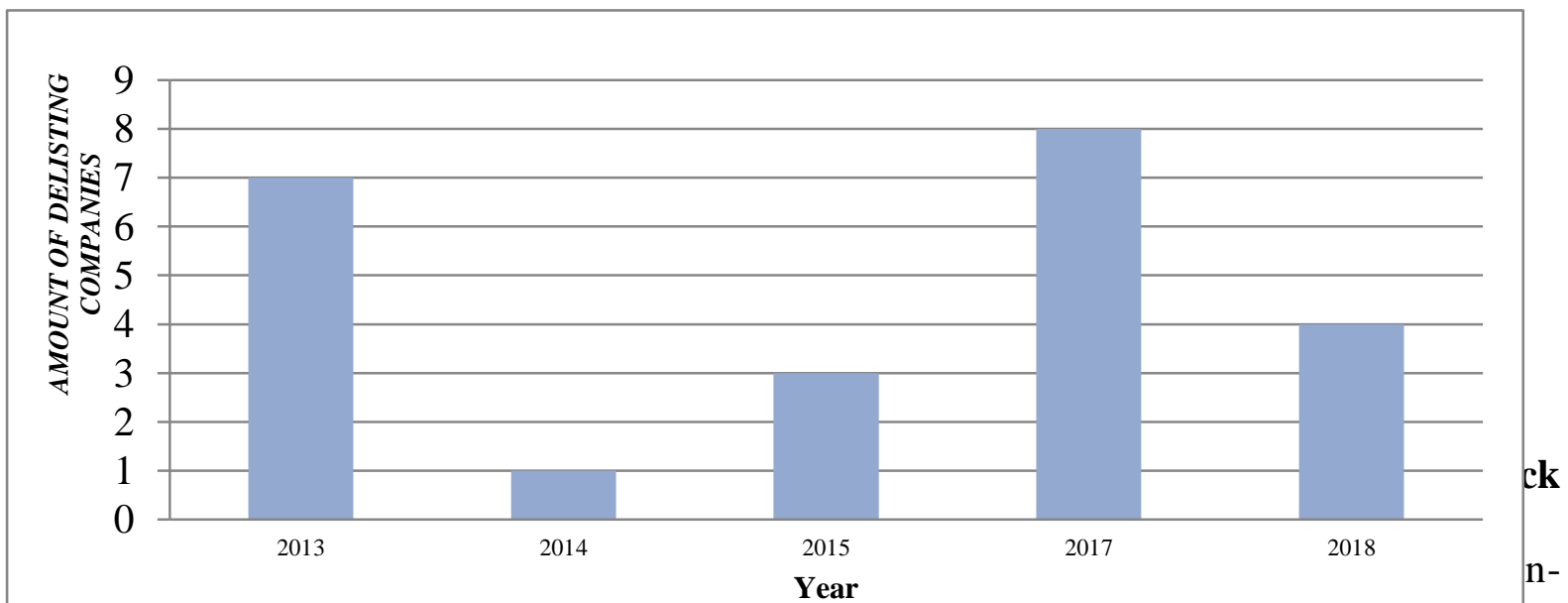

bankrupt companies. Using univariate discriminant analysis as a statistical test tool, Beaver concludes that the ratio of working capital funds flow / total assets and net income / total assets is able to distinguish bankrupt and non-bankrupt companies precisely by $90 \%$ and $88 \%$ of the sample used (Hadad, et al, 2003). The univariate approach is considered to have several potential problems, Altman (1968) criticized this approach by stating "the adaptation of univariate results for assessing bankruptcy potential of a firm is both theoretically and practically questionable and that the ratio analysis presented in univariate fashion is perceptible to faulty interpretation and potentially confusing. "Realizing that the company's financial condition is multidimensional (leverage, profitability, liquidity, activity, solvency, 
etc), Altman also uses the Multivariate Discriminant Analysis (MDA) approach as a development of Beaver's univariate analysis. Altman developed a bankruptcy prediction model by testing 22 financial ratios and finally obtained the five most significant financial ratios to predict bankruptcy in companies. Based on the description above, the authors are interested in making research with the title "Bankruptcy Prediction Model of Retail Trade Service Companies in the Indonesia Stock Exchange (Case Study for 2015-2017 Period)".

\section{LITERATURE REVIEW}

Several previous studies related to this research have been carried out by several previous researchers such as: Vita Permatasari (2011), Septian Dwi Prasetyo (2014), Orina Andra and Salma Taqwa (2014), Ayu Widuri Sucipto and Muazaroh (2016), Septy Indra Santoso , Dwi Yana Amalia Sari Fala, An Nisaa Nur Khoirin (2017), Nurul Fahmiwati and Luhgiatno (2017), Moch Bisyri Effendi and Titis Puspitaningrum Dewi Kartika (2017), Dean Subhan Saleh (2018).

Financial distress is financial difficulty refers to the inability of companies to pay bonds when they are due (William H. Beaver, Maria Correia and Maurren McNichols, 2012: 3).

Financial ratios are numbers obtained from the results of a comparison of one financial statement post with another post that has a relevant and significant relationship. (Sofyan Syafri Harahap, 2011: 297)

Current Ratio

Current ratio is the ratio used to show the ability of a company to meet all short-term obligations that will soon mature by using its current assets. This ratio shows the amount of current liabilities covered by current assets (Kieso, Waygandt, and Warfield, 2011: 693). The formula used is as follows:

$$
\text { Current Ratio }=\frac{\text { Current Asset }}{\text { Current Debt }}
$$

Quick Ratio

Quick ratio is a ratio that shows the ability of companies to meet or pay obligations or current debt with current assets without taking into account the value of inventory (inventory). This means ignoring the value of inventory, by deducting from total current assets. This is done because the inventory is considered to require a relatively longer time to cash, if the company needs funds quickly to pay its obligations compared to other current assets (Irham Fahmi, 2014: 124), the formula used is as follows:

$$
\text { Quick Ratio }=\frac{\text { Current Asset }- \text { Inventory }}{\text { Current Debt }}
$$

Cash Ratio

Cash ratio is a tool used to measure how much cash is available to pay debts. The availability of cash can be shown from the availability of cash funds or cash equivalents such as checking or savings accounts in banks (which can be withdrawn at any time). It can be said that this ratio shows the real ability of the company to pay its short-term debts. The formula used is as follows:

$$
\text { Cash Ratio }=\frac{\text { Cash }+ \text { Bank }}{\text { Current Debt }}
$$


Working Capital to Total Assets

Working capital is net working capital, which is part of real current assets that can be utilized to finance a company's operations without disrupting its liquidity (Bambang Riyanto, 2008). If the company's operations are smooth, it is expected that the company's revenue can also increase. And of course, if income increases, the profits will also increase. The WCTA formula is as follows:

$$
\text { WCTA }=\frac{\text { Current Asset }- \text { Current Debt }}{\text { Total Asset }}
$$

Debt to Asset Ratio (DAR)

Debt to Asset Ratio is a debt ratio that is used to measure the ratio between total debt to total assets. In other words, how much the company's assets are financed by debt or how much the company's debt affects the management of assets. If the ratio is high, it means that funding with more debt will make it more difficult for companies to obtain additional loans because it is feared that the company will not be able to cover its debts with the assets they have. Similarly, if the ratio is low, the smaller the company is financed with debt. The formula for finding a debt to asset ratio can be used as follows :

$$
\text { Debt to Asset Ratio }=\frac{\text { Total Debt }}{\text { Total Asset }}
$$

Debt to Equity Ratio (DER)

Debt to Equity Ratio is the ratio used to assess debt to equity. This ratio is sought by comparing all debt, including current debt and all equity. This ratio is useful to know the amount of funds provided by the borrower (creditor) with the owner of the company. In other words, this ratio serves to find out every rupiah of its own capital that is used for debt guarantees. The formula to find the debt to equity ratio can be used as a comparison between total debt and total equity as follows:

$$
\text { Debt to Equity Ratio }=\frac{\text { Total Debt }}{\text { Total Equity }}
$$

Time Interest Earned

Time Interest Earned is a ratio to find the amount of interest earned. This ratio is interpreted by James C. Van Home as well as the company's ability to pay interest costs. The number of times interest earned or Time Interest Earned is a ratio to measure the extent to which income can decrease without making the company feel ashamed of not being able to pay its annual interest costs ( $\mathrm{J}$ Fred Weston). The formula for finding Time Interest Earned can be used in the following way:

$$
\text { Time Interest Earned }=\frac{\text { EBIT }}{\text { Interest }}
$$

\section{Working Capital Turn Over}

The capital turnover ratio is used to assess how much working capital revolves in a given period. This ratio shows the relationship between working capital and sales and shows how much sales the company can get (the amount of rupiah) for each rupiah of working capital (Munawir, 2012: 80). Working capital turnover is calculated by the formula:

$$
\text { Working Capital Turnover }=\frac{\text { net sales }}{\text { Working Capital }}
$$


Fixed Assets Turn Over

The fixed assets turnover ratio is the ratio used by the company to measure the turnover of all assets owned by the company. The formula used is as follows:

$$
\text { Turnover of Fixeed Asset }=\frac{\text { Sales }}{\text { Total Fixed Asset }}
$$

Receivable Turn Over

Receivables owned by a company have a close relationship with the volume of credit sales. The higher the ratio shows the working capital invested in low receivables, conversely if the ratio is lower means there is over investment in receivables so that it requires further analysis (Munawir, 2012: 75) The formula used is as follows:

$$
\text { Receivable Turn Over }=\frac{\text { Sales }}{\text { Account Receivable }}
$$

Total Assets Turnover

Total asset turnover is the ratio used by the company to measure the turnover of all assets owned by the company. The formula used is as follows:

$$
\text { Total Asset Turnover }=\frac{\text { Sales }}{\text { Total Asset }}
$$

Inventory Turn Over Ratio

The financial ratios used in managing and evaluating inventory levels are the inventory turnover ratios. Inventory turnover ratio (inventory turnover ratio), measuring the number of times the average inventory sold during a period (Kieso and Weygandt, translated by Herman Wibowo, 2008: 402). The inventory turnover ratio is calculated using the formula:

$$
\text { Inventory Turnover }=\frac{\text { Cost of Good Sold }}{\text { Average Inventory }}
$$

Cash Turnover Ratio

Cash turnover is a comparison between sales and the average cash amount. Cash turnover rate is a measure of the efficiency of cash use by the company. Because the level of cash turnover illustrates the speed of cash flow of cash that has been invested in working capital (Riyanto, 2011: 95). The cash turnover ratio is measured using the following formula:

$$
\text { Cash Turnover }=\frac{\text { Net Sales }}{\text { Average Cash and Cash Inventory }}
$$

\section{Net Profit Margin (NPM)}

The relationship between net income after tax and sales shows management's ability to run the company until it is quite successful in recovering / controlling the price of goods / services, operating expenses, depreciation, loan interest and taxes. This ratio also shows the ability of management to set aside certain margins as a reasonable compensation for company owners who still provide capital with a risk. Simply put, the net profit margin can be formulated as follows:

$$
\text { Net Profit Margin }=\frac{\text { Earning Before Interest Tax }(E B I T)}{\text { Sales }}
$$




\section{Operating Profit Margin (OPM)}

Operating Profit Margin describes the "pure profit" received for each rupiah from the sale made. Gitman (2008: 65) reveals that OPM measures the percentage of each sale remaining after all costs and expenses other than interest, taxes, and preferred stock dividends. The higher the OPM value, the better the operation of a company. Operating Profit Margin is calculated using the formula:

$$
\text { Operating Profit Margin }=\frac{\text { Operation Profit }}{\text { Sales }}
$$

\section{Gross Profit Margin (GPM)}

Gross Profit Margin is the ratio or consideration between the company's gross profit and the level of sales achieved in the same period. Gross profit margin ratio data from several periods will be able to provide information about the tendency of gross margin obtained and when compared with the standard ratio will be known whether the margins obtained by the company are already high or vice versa (Munawir, 2010: 99). Gross Profit Margin Formula:

$$
\text { Gross Profit Margin }=\frac{\text { Gross Profit }}{\text { Net Sales }}
$$

Return on Equity (ROE)

The return on equity ratio shows the extent to which the company manages its own capital effectively, and measures the level of return on investment made by the capital owner or shareholder of the company. This can be calculated from the following formula:

$$
\text { Return On Equity }=\frac{\text { Earning Before Interest Tax }(E B I T)}{\text { Equity }}
$$

Return On Asset (ROA)

Return on Assets is a measurement of the overall ability of the company in generating profits with the total amount of assets available in the company. ROA is also a measure of the effectiveness of management in managing its assets. According to Munawir (2012: 89) Return on assets itself is one form of profitability ratios intended to be able to measure the ability of a company with the total funds invested in assets used for its operations to generate profits. The ROA formula is as follows:

$$
\text { Return On Asset }=\frac{\text { Earning Before Interest Tax }(E B I T)}{\text { Asset }}
$$

Return On Investment (ROI)

According to Harahap (2013: 63), ROI is a ratio that shows how much net income a company gets when measured by the value of assets. The higher this ratio the better the state of a company. ROI can be calculated using the following formula:

$$
\text { Return On Investment }=\frac{\text { Earning After Tax }(E A T)}{\text { Investment }}
$$

Earning Per Share (EPS) 
According to Eduardus Tandelilin (2010: 374), Earning Per Share (EPS) shows the size of the company's net profit that is ready to be distributed to all shareholders of the company. Investors need to have a number of information related to the dynamics of stock prices in order to make decisions about company shares that are eligible to be chosen. Here's the Earning Per Share formula:

$$
\text { Earning Per Share }=\frac{\text { Net Profit After Tax }}{\text { Number of Shares Outstanding }}
$$

Based on the literature review above, the research theoretical framework is as follows:

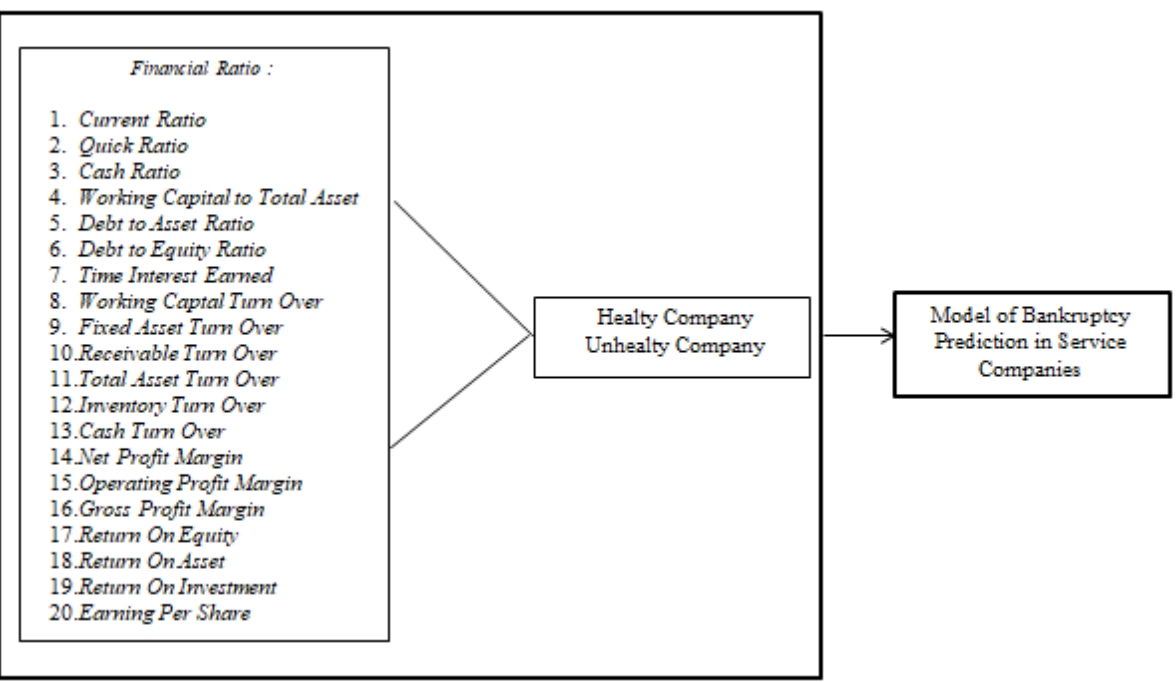

Figure 2. Theoretical Framework Schematic

\section{RESEARCH METHODS}

This research is a quantitative descriptive research that is research conducted by collecting, classifying, analyzing and interpreting the data obtained from the company so that it can provide an overview of the actual situation. The data used are financial data of retail trade service companies in the 2015-2017 period with a sample of 20 companies consisting of healthy and unhealthy service companies. The analytical method used is the Multiple Discriminant Analysis (MDA) of financial ratios, namely processing data that has been collected and can then provide interpretation of these results. Activities in data analysis require grouping data for each requested variable, performing calculations for the proposed hypothesis.

$R=a+b 1 X 1+b 2 X 2+b 3 X 3+\ldots+b n X n a$

\section{Where :}

$\mathbf{R}=$ Overall index

$\mathrm{b}=$ Discriminant coefficient

$x=$ independent variable

$\mathrm{n}=$ Number of variables 


\section{FINDINGS AND DISCUSSION}

Table 1. Normality Test - One Sample Kolmogorov Smirnov Test

\begin{tabular}{|c|c|c|c|c|c|c|c|c|c|c|}
\hline \multicolumn{11}{|c|}{ One-Sample Kolmogorov-Smirnov Test } \\
\hline & & CUR & QR & WCTA & DAR & DER & TIE & ROE & ROA & EPS \\
\hline $\mathrm{N}$ & & 60 & 60 & 60 & 60 & 60 & 60 & 60 & 60 & 60 \\
\hline \multirow{3}{*}{ Normal Parameters ${ }^{\mathrm{a}, \mathrm{b}}$} & Mean & 2.3982 & 3.4693 & 3.0118 & 2.4933 & 3.3722 & 2.3840 & 2.3328 & 2.0990 & 4.2112 \\
\hline & Std. & 1.8749 & 2.4436 & 1.5773 & 1.5814 & 2.0182 & 1.3478 & 1.5656 & 1.4695 & 2.3641 \\
\hline & Deviation & 7 & 2 & 8 & 6 & 3 & 1 & 8 & 5 & 9 \\
\hline \multirow{3}{*}{$\begin{array}{l}\text { Most Extreme } \\
\text { Differences }\end{array}$} & Absolute & .114 & .112 & .110 & .111 & .103 & .112 & .113 & .114 & .112 \\
\hline & Positive & .114 & .112 & .110 & .111 & .103 & .112 & .113 & .114 & .112 \\
\hline & Negative & -.100 & -.088 & -.046 & -.101 & -.099 & -.105 & -.068 & -.088 & -.096 \\
\hline \multicolumn{2}{|l|}{ Test Statistic } & .114 & .112 & .110 & .111 & .103 & .112 & .113 & .114 & .112 \\
\hline \multicolumn{2}{|l|}{ Asymp. Sig. (2-tailed) } & $.051^{\mathrm{c}}$ & $.057^{\mathrm{c}}$ & $.071^{\mathrm{c}}$ & $.064^{\mathrm{c}}$ & $.178^{\mathrm{c}}$ & $.060^{\mathrm{c}}$ & $.056^{\mathrm{c}}$ & $.052^{\mathrm{c}}$ & $.057^{\mathrm{c}}$ \\
\hline
\end{tabular}

a. Test distribution is Normal.

b. Calculated from data.

c. Lilliefors Significance Correction.

Source : Output SPSS 25.0, 2019.

From the results of the One Sample Kolmogorov Smirnov Test normality test, of the twenty ratios used as research variables only nine were ratios that can be used as research variables with a significance of $>0.05$ namely Current Ratio, Quick Ratio, Working Capital to Asset, Debt to Asset Ratio, Debt variables to Equity Ratio, Time Interset Earned, Return on Equity, Return on Assets and Earning Per Share.

\section{Tabel 2. Test of Equality of Group Means}

\begin{tabular}{|c|c|c|c|c|}
\hline \multicolumn{5}{|c|}{ Wilks' Lambda } \\
\hline Test of Function(s) & Wilks' Lambda & Chi-square & Df & Sig. \\
\hline 1 & .624 & 26.688 & 3 & .000 \\
\hline
\end{tabular}

In table 2 Wilk's Lambda known statistical significance value of $0,000<0.05$ which means that there are significant differences between healthy and unhealthy service companies.

Table 3. Test the Independent Variables of the Stepwise Method 
Variables Entered/Removed ${ }^{\mathrm{a}, \mathrm{b}, \mathrm{c}, \mathrm{d}}$

\begin{tabular}{|c|c|c|c|c|c|c|c|c|c|}
\hline \multirow[b]{3}{*}{ Step } & \multirow[b]{3}{*}{ Entered } & \multicolumn{8}{|c|}{ Wilks' Lambda } \\
\hline & & Statisti & & & & & Exa & ct $F$ & \\
\hline & & $\mathrm{c}$ & df1 & df2 & df3 & Statistic & df1 & $\mathrm{df} 2$ & Sig. \\
\hline$\overline{1}$ & EPS & .764 & 1 & 1 & 58.000 & 17.886 & 1 & 58.000 & .000 \\
\hline 2 & DER & .686 & 2 & 1 & 58.000 & 13.057 & 2 & 57.000 & .000 \\
\hline 3 & ROE & .624 & 3 & 1 & 58.000 & 11.271 & 3 & 56.000 & .000 \\
\hline
\end{tabular}

At each step, the variable that minimizes the overall Wilks' Lambda is entered.

a. Maximum number of steps is 18 .

b. Maximum significance of $\mathrm{F}$ to enter is .05 .

c. Minimum significance of $F$ to remove is .10.

d. F level, tolerance, or VIN insufficient for further computation.

Source : Output SPSS 25.0, 2019.

Table 3 shows the results of nine variables in the MDA model that can be entered in the discriminant equation starting from the variable that has the largest $\mathrm{F}$ statistic number. In the first stage, the calculated F value for the EPS (Earning Per Share) variable is 17,886, then at this stage the EPS (Earning Per Share) variable is selected. Based on the Wilk's Lambda test this EPS variable has a significantly smaller value than 0.05 which is equal to 0,000 . Furthermore, the DER variable (Debt to Equity Ratio) was chosen to be a discriminator variable with a significantly smaller value of 0.05 in the amount of 0,000 with an F count of 13,057. The ROE (Return On Equity) variable is also a discriminator variable with a calculated $F$ value of 11,271 with a significant value of 0,000 less than 0.05 .

Table 4. Correlation Test Summary of Canonical Discriminate Function

\begin{tabular}{|c|c|c|c|c|}
\hline \multicolumn{5}{|c|}{ Eigenvalues } \\
\hline Fun & Eigenvalue & $\begin{array}{c}\% \text { of } \\
\text { Variance }\end{array}$ & $\begin{array}{c}\text { Cumulative } \\
\%\end{array}$ & $\begin{array}{l}\text { Canonical } \\
\text { Correlation }\end{array}$ \\
\hline 1 & $.604^{\mathrm{a}}$ & 100.0 & 100.0 & .614 \\
\hline
\end{tabular}

a. First 1 canonical discriminant functions were used in the analysis.

Source : Output SPSS 25.0, 2019.

In table 4 above there is a Cannonical Correlation value of 0.614 indicating a strong closeness with the scale of the association scale 0 to 1 , so it can be concluded that variations between groups of retail trade service companies categorized as unhealthy and healthy can be explained on the variable Earning Per Share, Return On Equity, and Debt to Equity Ratio.

Table 5. Test of Canonical Discriminant Function Coefficients

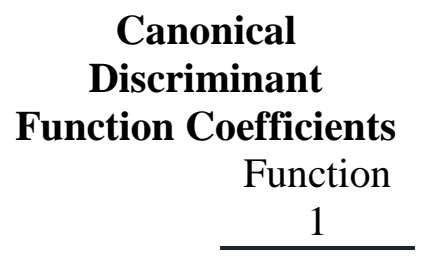




\begin{tabular}{lr}
\hline DER & .292 \\
\hline ROE & .342 \\
\hline EPS & .336 \\
\hline (Constant) & -3.197 \\
\hline
\end{tabular}

Unstandardized

coefficients

Source : Output SPSS 25.0, 2019.

In table 5 it appears that there are three variables that influence the formation of discriminant function, namely the variable Debt to Equity Ratio, Return On Equity and Earning Per Share. So the discriminant function that is formed is:

\section{$R=-3,197+0.292$ Debt to Equity Ratio + 0.342 Return On Equity + 0.336 Earning Per Share}

Based on the formula above as follows:

1. If DER, ROE, EPS are the same as the sample, then $R=-3.197+0.292$ Debt to Equity Ratio + 0.342 Return On Equity + 0.336 Earning Per Share. That is, the company is in bankrupt condition.

2. If DER is still the same unit as ROE, EPS in retail companies, then $\mathrm{R}=-3.197+0.292$ Debt to Equity Ratio + 0.342 Return On Equity + 0.336 Earning Per Share of the company will potentially be bankrupt.

3. Debt to Equity Ratio is 0.292 which means that if the company has a high Debt to Equity Ratio then the company will potentially go bankrupt.

4. Return on Equity is 0.342 which means the return on equity shows the extent to which the company manages its own capital effectively, and measures the level of return on investment made by the capital owner or shareholder of the company, if the company is unable to manage equity effectively and efficiently then the value ROE will be negative so the company can potentially go bankrupt.

5. Earning Per Share is worth 0.336, which means EPS measures the strength of profitability between the company concerned and the comparison company, if the company is unable to compete with similar or unrelated companies so that investors are less interested in the company so that EPS is a negative company and the company will potentially go bankrupt.

Table 6. Results of Cut Off Values

\section{Functions at}

Group Centroids

Compan Function

\begin{tabular}{ll}
$\mathrm{y}$ & 1 \\
\hline Unhealt & -.764
\end{tabular}

y

Healthy $\quad .764$




\author{
Unstandardized \\ canonical \\ discriminant \\ functions evaluated \\ at group means
}

Source : Output SPSS 25.0, 2019.

From the results of table 6. Functions at Group Centroids, provide information about the average discriminant score (centroid). Centroid for the unhealthy retail trade services group of $-0,764$ and the healthy trade category of retail trade group of 0.764 so the cut-off value. The value of the function obtained will be adjusted to the calculated cut-off formula:

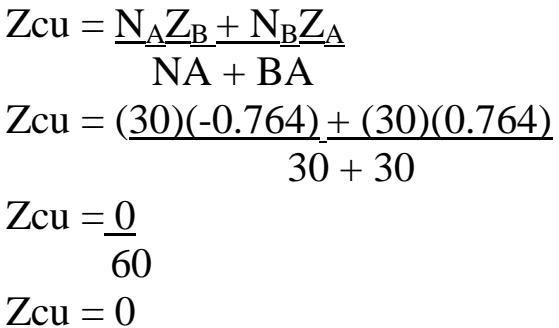

So for the Multiple Discriminant Analysis (MDA) model, the determination of the boundary value is based on the average value of the Z-Score of each retail trade sector service company that is obtained by 0 . The standard used to assess whether the service company is categorized as healthy or unhealthy is:

a. If the Z-Score is $<0$, retail service sector companies are categorized as not healthy.

b. If the Z-Score is $>0$, the retail sector service company is categorized as healthy.

Tabel 7. Classification Result

\begin{tabular}{|c|c|c|c|c|c|}
\hline \multicolumn{6}{|c|}{ Classification Results $^{\mathrm{a}, \mathrm{c}}$} \\
\hline & & \multirow[b]{2}{*}{ Code_Company } & \multicolumn{2}{|c|}{$\begin{array}{l}\text { Predicted Group } \\
\text { Membership }\end{array}$} & \multirow[b]{2}{*}{ Total } \\
\hline & & & Unhealthy & Healthy & \\
\hline \multirow[t]{4}{*}{ Original } & \multirow[t]{2}{*}{ Count } & Unhealty & 22 & 8 & 30 \\
\hline & & Healthy & 7 & 23 & 30 \\
\hline & \multirow[t]{2}{*}{$\%$} & Unhealty & 73.3 & 26.7 & 100.0 \\
\hline & & Healthy & 23.3 & 76.7 & 100.0 \\
\hline \multirow[t]{4}{*}{ Cross-validated $^{\mathrm{b}}$} & \multirow[t]{2}{*}{ Count } & Unhealty & 21 & 9 & 30 \\
\hline & & Healthy & 8 & 22 & 30 \\
\hline & \multirow[t]{2}{*}{$\%$} & Unhealty & 70.0 & 30.0 & 100.0 \\
\hline & & Healthy & 26.7 & 73.3 & 100.0 \\
\hline
\end{tabular}

a. $75.0 \%$ of original grouped cases correctly classified.

b. Cross validation is done only for those cases in the analysis. In cross validation, each case is classified by the functions derived from all cases other than that case. c. $71.7 \%$ of cross-validated grouped cases correctly classified.

Source: Output SPSS 25.0, 2019. 
From table 7 can illustrate the initial model (original) with the classification of discriminant model results (predictive group membership). To test the accuracy of the grouping of healthy and unhealthy retail trade service companies in this table states in the column are two predictive values of the dependent variable namely the condition of service companies, in this study unhealthy retail trade service companies (0) and healthy retail trade service companies (1). In a perfect model, everything will be on a diagonal with a $100 \%$ accuracy forecast. In table 7 it can be seen that the prediction of unhealthy service companies is 30 unhealthy service companies, while in the actual observation line there are 21 unhealthy companies. So, the accuracy of the Multiple Discriminant Analysis (MDA) model for unhealthy service companies is $73.3 \%$. The prediction of healthy service companies is that there are 30 service companies that are in the healthy category, while the actual observation of healthy service companies is 23. So, the accuracy of the Multiple Discriminant Analysis (MDA) model for healthy retail trade service companies is $76.7 \%$. So that the discriminant function is able to classify cases correctly as much as $88.3 \%$.

$$
\text { Average Ability }=\underline{73.3+76.7}=75 \%
$$

2

\section{REFERENCE}

Fahmi, Irham. (2012). Financial Statement Analysis. 2nd printing. Alfabeta. Bandung. Gamayuni, Miss Rika. (2009). "Various Alternative Bankruptcy Prediction Models". Journal of Accounting and Finance, Vol.14, No.1, pp. 75-89.

Gitman, L. J. (2008). Principles of Managerial Finance. 12th ed. Pearson Education Inc. United State.

Harahap, Sofyan Syafri. (2011). Revised Edition of Theory of Accounting 2011. Rajawali Press. Jakarta.

Kieso, D. E., Weygandt, J. J., and Warfield, T. D. (2011). Intermediate Accounting Volume 1 IFRS Edition. United States of America: Willey.

Munawir, S. (2012). Financial Information Analysis. Liberty. Yogyakarta. Permatasari, Vita. (2011). "Comparison of Logit Models and Multiple Discriminant Models Analysis (MDA) as Early Warning Systems (EWS) to Predict Conditions Troubled with National Private Foreign Exchange and Non-Foreign Exchange Banks in Indonesia". Thesis. Riyanto, Bambang. (2008). Fundamentals of Corporate Spending. GPFE. Yogyakarta. 